\title{
Integrin-linked kinase can facilitate syncytialization and hormonal differentiation of the human trophoblast-derived BeWo cell line Trina $M$ Butler ${ }^{1}$, Pia A Elustondo1 ${ }^{1}$, Greg E Hannigan ${ }^{2,3}$ and Daniel J MacPhee*1
}

Address: ${ }^{1}$ Division of BioMedical Sciences, Faculty of Medicine, Health Sciences Centre, Memorial University of Newfoundland, St. John's, NL, A1B 3V6, Canada, ${ }^{2}$ Centre for Cancer Research, Monash Institute of Medical Research, 246 Clayton Rd., Clayton Melbourne 3168, Australia and ${ }^{3}$ Research Institute, Hospital for Sick Children, 555 University Avenue, Toronto ON, M5G 1X8, Canada

Email: Trina M Butler - x76tmk@mun.ca; Pia A Elustondo - pia@mun.ca; Greg E Hannigan - Greg.Hannigan@med.monash.edu.au; Daniel J MacPhee* - dmacphee@mun.ca

* Corresponding author

Published: 22 May 2009

Reproductive Biology and Endocrinology 2009, 7:51 doi:|0.1|86/|477-7827-7-51

This article is available from: http://www.rbej.com/content/7///5 I

(c) 2009 Butler et al; licensee BioMed Central Ltd.

This is an Open Access article distributed under the terms of the Creative Commons Attribution License (http://creativecommons.org/licenses/by/2.0), which permits unrestricted use, distribution, and reproduction in any medium, provided the original work is properly cited.

\begin{abstract}
Background: In the fusion pathway of trophoblast differentiation, stem villous cytotrophoblast cells proliferate and daughter cells differentiate and fuse with existing syncytiotrophoblast to maintain the multi-nucleated layer. Integrin-linked kinase (ILK) is highly expressed in Ist and 2nd trimester villous cytotrophoblast cells, yet barely detectable in syncytiotrophoblast, thus we examined the potential role of ILK in aiding trophoblast fusion.
\end{abstract}

Methods: The temporal/spatial expression and activity of ILK were determined in BeWo cells undergoing syncytialization by immunoblot and immunofluorescence analyses. BeWo cells were also transfected with PEGFP expression vectors containing wildtype or two mutant ILK cDNA constructs. The incidence of cell fusion in transfected cells grown under syncytialization conditions was then scored by the presence or absence of E-cadherin immunostaining. Beta-hCG expression in transfected cells, a marker of syncytiotrophoblast hormonal differentiation, was also similarly assessed.

Results: ILK catalytic activity increased and ILK began to increasingly localize to BeWo cell nuclei during syncytialization in correlation with increased pAkt and Snail protein expression. Syncytialization was also significantly elevated $(p<0.05)$ in BeWo cells expressing constitutively active (ca)-ILK vs cells containing empty vector or dn-ILK. Furthermore, cytoplasmic Beta-hCG expression markedly increased $(\mathrm{p}<0.05)$ in cells expressing wt- and ca-ILK.

Conclusion: ILK-facilitated syncytialization is dependent, at least in part, on ILK catalytic activity while hormonal differentiation appears dependent on both ILK-associated protein interactions and catalytic activity. This study demonstrates that ILK plays a novel role in BeWo syncytialization and differentiation, perhaps through an ILK-Akt-Snail pathway, and implicates ILK in the same process in villous cytotrophoblasts in vivo. 


\section{Background}

The human placenta is a critical organ formed during pregnancy that possesses an array of specialized metabolic, hormonal, and immunological functions that control the growth and viability of the fetus and, in turn, the health of the mother [1-4]. The importance of proper placental development to the health and well being of the fetus and mother is illustrated in conditions that arise during pregnancy such as preeclampsia, gestational diabetes and intrauterine growth restriction, that are thought to be the result of placental abnormalities [5].

In the human fetal placenta, the floating villi represent the majority of the chorionic villi and are bathed in maternal blood to function in hormone transport and to aid in the exchange of gases, nutrients and waste between the mother and fetus $[2,5]$. The floating villi consist of an outer multinucleated syncytiotrophoblast layer, an underlying mitotically active mononuclear cytotrophoblast layer and a stroma [4]. In the cytotrophoblast layer, polarized stem cytotrophoblast cells proliferate and daughter cells then differentiate and fuse with existing syncytiotrophoblast to maintain the multi-nucleated layer [reviewed by [6]]. Morphometric analyses have indicated that in the first trimester there is an excess of villous cytotrophoblast cells fusing with the syncytiotrophoblast - likely necessary for the metabolic integrity of the syncytiotrophoblast [7], although Ellery et al [8] has recently demonstrated that a proportion of nuclei in the syncytiotrophoblast are actively engaged in transcription in accordance with the high metabolic and secretory activity of the tissue. While proliferation of villous cytotrophoblast cells falls with advancing gestation, the cytotrophoblast layer is not entirely discontinuous. Mori et al [9] and Jones et al [10] have calculated 45-80\% continuity of the cell layer at term with cytotrophoblast cells being transformed into flat cells with many thin cellular interdigitating processes. While the events leading to maintenance of the cytotrophoblast stem cell population as well as cytotrophoblast differentiation and fusion are poorly understood, it is becoming clear that initiation of an apoptosis cascade occurs early in differentiation $[11,12]$. A flip of phosphatidylserine within the cytotrophoblast cell membrane is also associated with cytotrophoblast fusion $[7,13]$. Since the villous cytotrophoblast and syncytiotrophoblast comprise the epithelial covering of the chorionic villi that is in contact with maternal blood, any disturbances in the processes of cytotrophoblast proliferation and fusion of cytotrophoblast with overlying syncytiotrophoblast can seriously perturb the turnover and function of the syncytiotrophoblast layer and ultimately may contribute to development of fetal growth restriction or preeclampsia [14].

Research has demonstrated that syncytin-1, a retroviral envelope protein, appears to have a direct role in human trophoblast fusion [15]. Furthermore, glial cells missing-1
(GCM1), a transcription factor, appears to be upregulated in pre-fusing cytotrophoblast and to regulate syncytin-1 mRNA expression [15-17]. Along with these findings, other proteins or groups of proteins such as protein tyrosine kinases and protein tyrosine phosphatases with a variety of other known functions also appear to play important roles in the fusion pathway $[18,19]$. An intracellular serine/threonine kinase named Integrin-linked kinase (ILK) localizes to focal adhesions and is critically involved in the adhesion of cells to their extracelluar environment and in signal transduction [20,21]. ILK interacts with the cytoplasmic domains of $\beta$-integrins and numerous cytoskeletal associated proteins and has been found to mediate protein-protein interactions.

Recently, Elustondo et al [22] reported that ILK was highly detectable by immunoblot analyses in human chorionic villous tissue lysates throughout gestation. It was also highly expressed in situ in villous cytotrophoblast cells and in stromal mesenchyme in first trimester and early second trimester human chorionic floating villi; however, it was scarcely detected in the syncytiotrophoblast layer. The adherens junction protein E-cadherin mediates homophilic calcium- dependent cell adhesion in neighbouring cells and is also highly detectable at points of cytotrophoblast cell-cell contact $[23,24]$. E-cadherin expression markedly decreases with remodeling of cell-cell adhesion complexes associated with differentiation and subsequent fusion of cytotrophoblast to syncytiotrophoblast [24] and, thus, presence/absence of the protein can be used to assess trophoblast syncytialization [25-27]. As yet, the mechanism(s) underlying the downregulation of E-cadherin expression in villous cytotrophoblast undergoing the morphogenetic process of syncytialization is unknown.

Hannigan et al [28] has demonstrated that over-expression of ILK in epithelial cells results in disrupted cell-cell adhesion. ILK also downregulates E-cadherin expression through activation of the transcriptional repressor Snail, independent of $\beta$-catenin/T cell factor (TCF7) regulation [29]. Based on the reported role of ILK in regulating E-cadherin expression and the known expression of both ILK and E-cadherin expression in the cytotrophoblast of human chorionic villi during pregnancy, we hypothesized that ILK could be a player in regulating the differentiation and fusion of cytotrophoblast into the syncytiotrophoblast via the downregulation of E-cadherin. To begin testing this hypothesis we employed a well documented cell line model, BeWo cytotrophoblast cells, for the study of trophoblast syncytialization $[30,31]$.

\section{Methods \\ Cell culture}

The BeWo cell line was purchased from the American Type Culture Collection (Cat. \#CCL-98, Manassas, VA, USA). This cell line was originally derived from a human tro- 
phoblast choriocarcinoma and is well known to undergo syncytialization upon forskolin treatment [32]. This cell line model is ideal for experiments because syncytialization can be controlled with syncytialization of up to $80 \%$ [33]. They can be grown under proliferating conditions indefinitely where they exhibit an epithelial phenotype or under syncytialization conditions where it is well known that BeWo cells express markers of syncytiotrophoblast such as $\beta$-hCG, syncytin, and markedly decreased E-cadherin and desmoplakin expression [15,24,33-36].

Cells were cultivated in $75 \mathrm{~cm}^{2}$ culture flasks in Ham's F-12 media with L-glutamine (Cat. \#11765-062; Invitrogen Ltd., Burlington, Ontario, Canada) supplemented with $10 \%$ fetal bovine serum (Cat. \#16000-044; Invitrogen) and 100 U penicillin/100 $\mu \mathrm{g}$ (Cat. \#15140-122; Invitrogen) as has been described elsewhere [37]. The BeWo cells were maintained under standard culture conditions of $5 \%$ carbon dioxide in air at $37^{\circ} \mathrm{C}$ with medium renewal on a daily basis. This tissue culture media formulation and associated culture parameters were designated "proliferating conditions". Once cells reached $\sim 80 \%$ confluency they were passaged into new tissue culture flasks with new media at a ratio of 1:4. For culture of BeWo cells to promote syncytialization the same conditions as above were utilized except that the media was simply changed to Ham's F-12K media (Cat. \# 21127-022) containing $25 \mu \mathrm{M}$ Forskolin (Cat. \#F6886; Sigma Chemical Co, St. Louis, Missouri, USA). This media formulation and culture parameters were designated as "syncytialization conditions".

\section{BeWo transfection and determination of syncytialization and $\beta$-hCG expression}

BeWo cells were counted with a haemocytometer and the concentration was adjusted to $2.5 \times 10^{5} \mathrm{cells} / \mathrm{ml}$. Cells were initially seeded on either $22 \times 22 \mathrm{~cm}$ glass coverslips, seated in $35 \mathrm{~mm}$ tissue culture dishes, or in 6 well plates and cultivated in proliferating conditions as described above. When the cells reached approximately $80 \%$ confluence they were washed with media without FBS or antibiotics and transiently transfected with $2.0 \mu \mathrm{g}$ of empty pEGFP-C3 vector (Cat. \#6082-1; BD Clontech), pEGFPC3 containing human wild-type (wt)-ILK, pEGFP-C3 containing dominant-negative human E395K (dn)-ILK, or pEGFP-C3 containing a constitutively active human S343D (ca)-ILK construct and $8.0 \mu \mathrm{l}$ of Lipofectamine 2000 (Cat. \#11668-027; Invitrogen). Transfections were conducted according to the manufacturer's detailed instructions. Six hours after transfection the cells were cultivated in syncytialization conditions and the media replenished 24 hours after transfection.

The incidence of syncytialization in transfected cells was scored by the presence or absence of E-cadherin immunostaining in twenty microscopic high power fields of view (400× observed magnification). The use of E-cad- herin immunostaining has been utilized in the past for such assessments of trophoblast fusion [25-27]. Syncytialization was considered genuine when at least 3 or more nuclei were present in the same cytoplasm. The incidence of $\beta$-hCG expression in transfected cells was also scored by the presence or absence of $\beta$-hCG immunostaining in twenty microscopic high power fields of view (400x observed magnification).

\section{Immunocytochemical analysis \\ BeWo cell syncytialization time course}

BeWo cells were initially seeded on $22 \times 22 \mathrm{~mm}$ glass coverslips ( $2.5 \times 10^{5}$ cells/coverslip) seated in $35 \mathrm{~mm}$ culture dishes and grown in proliferating conditions for 24 hours. Cells were then fixed in 4\% paraformaldehyde/PBS for 15 minutes under these proliferating conditions $(0 \mathrm{~h})$ or subsequently at $3,6,9,12,18,24,36$, or $48 \mathrm{~h}$ after initiation of culture in syncytialization conditions. Cells were then washed once with $1 \times$ PBS for 5 minutes.

\section{ILK fusion protein overexpression}

For immunolocalization of E-cadherin or $\beta$-hCG in EGFPfusion protein expressing cells, forty eight hours after transfection BeWo cells were washed with $1 \times$ PBS for $2 \times$ 5 minutes each. The cells were then fixed in $4 \%$ paraformadehyde/PBS for 15 minutes and then washed once with $1 \times$ PBS for 5 minutes.

For immunocytochemical analyses, all cells were placed in PBS containing $0.1 \%$ Triton X-100 (PBT) for 15 minutes at room temperature and subsequently washed with $1 \times$ PBS for 5 minutes. The cells were then blocked in 5\% normal goat serum $/ 1 \%$ horse serum $/ 1 \%$ fetal bovine serum in PBS for $1 \mathrm{~h}$ at room temperature with constant agitation, then incubated for 1 hour at room temperature in appropriate primary antisera (Table 1). Affinity-purified mouse and rabbit IgG, at the same concentration as the primary antisera, served as negative controls for immunocytochemical analyses. After three washes in PBT, cells were incubated with appropriate secondary antisera (Table 1). The cells were then washed two times with PBT followed by a final wash in PBS. The cells were then mounted in Vectashield containing DAPI (Cat \# H-1200; Vector Laboratories Inc., Burlington, Ontario, Canada). All cells were observed using a Leica DM-IRE2 inverted microscope (Leica Microsystems, Richmond Hill, Ontario, Canada) equipped for epifluorescence illumination and attached to a Retiga Exi CCD camera (QImaging, Burnaby, B.C, Canada). Openlab Image Analysis software (Version 5.5; Improvision, Inc., Lexington, Massachusetts, USA) was used for image capture and analysis.

\section{Immunoblot analysis}

\section{BeWo cell syncytialization time course}

BeWo cells were initially seeded at $2.5 \times 10^{5}$ cells/well in $35 \mathrm{~mm}$ culture dishes in Ham's F12 media and cultured 
Table I: Antisera utilized for immunofluorescence and immunoblot analysis.

\begin{tabular}{|c|c|c|c|c|}
\hline Antisera & Method & Dilution & Company & Catalogue \# \\
\hline Mouse anti-ILK; Clone 65.I.9 & IF & $1: 100$ & Abcam, Ltd, Cambridge, MA, USA & ab49979 \\
\hline Rabbit anti-ILK & IB & $1: 2000$ & Cell Signaling Technology, Beverly, MA, USA & 3862 \\
\hline Rabbit anti-E-cadherin & IF & $\mathrm{I}: 250$ & Abcam, Ltd, Cambridge, MA, USA & $\mathrm{ab}|5| 48$ \\
\hline Mouse anti-E-cadherin, clone SHE78-7 & $\begin{array}{l}\text { IF } \\
\text { IB }\end{array}$ & $\begin{array}{l}I: 1000 \\
I: 10000\end{array}$ & EMD Biosciences, San Diego, CA, USA & 205602 \\
\hline Rabbit anti-hCG & IF & $\mathrm{I}: 500$ & Dako Canada, Inc, Mississauga, ON, Canada & A023I \\
\hline Rabbit anti-Snail & IB & $1: 1000$ & Abcam, Ltd, Cambridge, MA, USA & abl7732 \\
\hline Mouse anti-pAKTI (Ser 473); Clone 587FII & IF & $1: 100$ & Cell Signaling Technology, Beverly, MA, USA & 4051 \\
\hline Rabbit anti-pAKTI (Ser 473) & IB & $1: 1000$ & Cell Signaling Technology, Beverly, MA, USA & 9271 \\
\hline Anti-phospho-GSK3ß (Ser-9) & IB & $1: 1000$ & Cell Signaling Technology, Beverly, MA, USA & 9336 \\
\hline FITC-Sheep anti-Rabbit lgG & IF & $\mathrm{I}: 250$ & Sigma Chemical Co, St. Louis, MO, USA & F75I2 \\
\hline RRX-Donkey anti-Mouse IgG & IF & $\mathrm{I}: 150$ & Jackson ImmunoResearch Labs Inc, West Grove, USA & $715-295-150$ \\
\hline RRX-Donkey anti-Rabbit lgG & IF & $\mathrm{I}: 250$ & Jackson ImmunoResearch Labs Inc, West Grove, USA & $711-295-152$ \\
\hline ChromPure Mouse IgG & IF & N/A* & Jackson ImmunoResearch Labs Inc, West Grove, USA & $015-000-003$ \\
\hline ChromPure Rabbit IgG & IF & $\mathrm{N} / \mathrm{A}^{*}$ & Jackson ImmunoResearch Labs Inc, West Grove, USA & $011-000-003$ \\
\hline HRP-Goat anti-Rabbit lgG $(\mathrm{H}+\mathrm{L})$ & IB & $1: 20000$ & Pierce, Rockford, IL, USA & 31460 \\
\hline HRP-Goat anti-Mouse lgG $(\mathrm{H}+\mathrm{L})$ & IB & I:10000 & Pierce, Rockford, IL, USA & 31430 \\
\hline
\end{tabular}

IF: immunofluorescence, IB: immunoblot, FITC: Fluorescein isothiocyanate, RRX: Rhodamine-Red-X, HRP: horseradish peroxidase, *Dependent on concentration of primary antisera utilized

for 24 hours. Cells were then lysed from these culture conditions $(0 \mathrm{~h})$ or at $3,6,9,1218,24,36$, or $48 \mathrm{~h}$ after initiation of culture in syncytialization conditions. $250 \mu \mathrm{l}$ of $\mathrm{NP}-40$ lysis buffer (50 mM Tris pH 8.0, $150 \mathrm{mM} \mathrm{NaCl}, 1 \%$ Nonidet P-40) containing $100 \mu \mathrm{M}$ sodium orthovanadate and complete Mini EDTA-free protease inhibitors (Roche Molecular Biochemicals, Laval, Quebec, Canada) were added to the cells. Cells were harvested with a plastic cell scraper and homogenized with moderate pipetting. Samples were cleared by centrifugation and supernatants were retained for immunoblot analysis.

\section{ILK fusion protein overexpression}

BeWo cells were initially seeded at $3.5 \times 10^{5}$ cells/well in 6 well plates and transiently transfected with either the pEGFP -C3 vector or one of the pEGFP-C3 containing ILK constructs described above. Cells were then cultivated in syncytialization conditions at 6 and 24 hours post-transfection as described above. Forty- eight hours after transfection, $250 \mu \mathrm{l}$ of NP-40 lysis buffer ( $50 \mathrm{mM}$ Tris $\mathrm{pH}$ 8.0, $150 \mathrm{mM} \mathrm{NaCl}, 1 \%$ Nonidet P-40) containing $100 \mu \mathrm{M}$ sodium orthovanadate and complete Mini EDTA-free protease inhibitors (Cat. \# 11836170001; Roche Molecular Biochemicals, Laval, Quebec, Canada) were added to the cells. Cells were harvested with a plastic cell scraper and homogenized with moderate pipetting. Samples were cleared by centrifugation and supernatants were retained for immunoblot analysis.

For all immunoblot analyses, sample protein concentrations were determined by the Bradford Assay using the Bio-Rad protein assay dye reagent (Bio-Rad Laboratories, Mississauga, Ontario, Canada). Protein samples $(30 \mu \mathrm{g} /$ lane) were separated in $10 \%$ polyacrylamide gels under denaturing conditions and gels were blotted to Pierce 0.45 $\mu \mathrm{m}$ nitrocellulose membranes (MJS Biolynx, Inc, ON, Canada). Blots were washed with Tris buffered salineTween-20 (TBST; $20 \mathrm{mM}$ Tris base, $137 \mathrm{mM} \mathrm{NaCl}$, and $0.1 \%$ Tween 20, pH 7.6) and blocked with 5\% BSA/TBST for $1 \mathrm{~h}$. Appropriate antisera (Table 1) were incubated with blots at $4^{\circ} \mathrm{C}$ overnight with constant agitation. The next day, blots were washed with TBST and then incubated in relevant horseradish peroxidase (HRP)-conjugated goat secondary antisera for 1 hour at room temperature with constant agitation. Following washes in TBST, proteins were detected on immunoblots using the Pierce SuperSignal West Pico chemiluminescent substrate detection system (Cat \#34080; MJS Biolynx, Inc) and multiple exposures were generated to ensure the linearity of the film responses.

\section{$\beta$-hCG ELISA}

BeWo cells were either grown under proliferating or syncytialization conditions for 48 hours, with the media being replenished once at 24 hours after initial seeding. After 48 hours, the media was collected and the ELISA conducted with a $\beta$-hCG ELISA kit (Cat \# EIA-1469; DRG Diagnostics, New Jersey, USA) exactly according to the manufacturer's instructions.

\section{Nonradioactive IP kinase assay}

BeWo cells were seeded in $35 \mathrm{~mm}$ culture dishes at $2.5 \times$ $10^{5}$ cells/well and cultured in either proliferating conditions or syncytialization conditions as described above. After 48 hours of culture, the cells were lysed with NP-40 lysis buffer containing $100 \mu \mathrm{M}$ sodium orthovanadate 
and complete Mini EDTA-free protease inhibitors and protein concentrations determined as described previously. For immunoprecipitation, $4.0 \mu \mathrm{g}$ of mouse monoclonal ILK antisera or non-specific IgG (see Table 1) was added to $400 \mu \mathrm{g}$ of appropriate BeWo cell lysate and incubated overnight at $4{ }^{\circ} \mathrm{C}$ with gentle agitation. Fifty microlitres of TrueBlot anti-mouse IP beads (Cat \# 00-8811; eBiosciences, San Diego, California, USA) were added to each sample and incubated for 2 hours at $4^{\circ} \mathrm{C}$ with gentle rocking. Then ILK-antibody-bead complexes were centrifuged at $13,000 \times \mathrm{g}$ for 1 minute at $4{ }^{\circ} \mathrm{C}$ and subsequently washed $3 \times$ with $500 \mu \mathrm{l}$ of NP- 40 lysis buffer followed by 3 washes with $500 \mu \mathrm{l}$ of kinase buffer (Cat \# 9802; Cell Signaling). Complexes were then each suspended in $50 \mu \mathrm{l}$ of kinase buffer supplemented with $1.0 \mu \mathrm{l}$ of $10 \mathrm{mM}$ ATP (Cat \# 9804; Cell Signaling) and $1 \mu \mathrm{g}$ of GSK-3 $\beta$ fusion protein (Cat \# 9237; Cell Signaling) and incubated for 30 minutes at $30^{\circ} \mathrm{C}$. The reaction was then terminated with $12.0 \mu \mathrm{l}$ of $5 \times$ SDS polyacrylamide gel loading buffer followed by vortexing and centrifugation for 30 seconds at $14,000 \times$ g. All samples were heated to $95^{\circ} \mathrm{C}$ for 5 minutes prior to loading on $10 \%$ polyacrylamide gels and SDSPAGE followed by electroblotting to Pierce $0.45 \mu \mathrm{m}$ pore nitrocellulose membrane (MJS Biolynx, Inc). Immunoblot analyses of phosphorylated GSK-3 $\beta$ (Ser-9) and ILK proteins were then conducted.

\section{Data analysis}

Statistical analysis was performed with GraphPad Prism ${ }^{\circledast}$ version 5.01 (GraphPad Software, San Diego, California, USA). Statistical significance for the determination of the incidence of cell fusion and intracellular $\beta$-hCG expression were analyzed with a one-way analysis of variance (ANOVA) and a Newman-Keuls multiple comparisons test. Values were considered significantly different if $\mathrm{p}<$ 0.05 . Densitometric analyses of immunoblot data was conducted with a one-way ANOVA followed by pair wise comparison of data points with two tailed unpaired ttests.

\section{Results}

\section{ILK expression during BeWo syncytialization}

ILK protein was readily detectable in BeWo cell lysates from cells cultured under proliferating conditions (Fig. $1 \mathrm{~A} ; 0 \mathrm{~h}$ ). Upon culture in syncytialization-promoting conditions of Ham's F12K + 25 um Forskolin, ILK expression consistently decreased by $6 \mathrm{~h}$ of culture and was significantly lower by $12 \mathrm{~h}$ vs $0 \mathrm{~h}(\mathrm{p}<0.05)$. Expression quickly recovered and reached detection levels at $48 \mathrm{~h}$ of culture that were comparable to ILK expression at $0 \mathrm{~h}$. In contrast, ILK kinase activity, measured by phosphorylation of a GSK3 $\beta$ fusion protein, was markedly higher at $48 \mathrm{~h}$ of culture in syncytialization-promoting conditions compared to activity in cells cultivated in proliferating conditions (Fig. 1B). This result was also concomitant with increased syncytin protein expression and $\beta$-hCG secretion occurring in syncytializing BeWo cells, as has been previously described [35,36], compared to cells cultivated under proliferating conditions (Fig. 1C, D). These results thus indicate that ILK protein expression and activity are dynamically regulated during BeWo syncytialization.

The spatial localization of ILK also changed dynamically during BeWo syncytialization (Fig. 2). Under proliferating culture conditions $(0 \mathrm{~h})$, ILK was localized in the cell cytoplasm, at focal adhesion-like structures and particularly present at cell-cell adhesions marked by E-cadherin expression (Fig. 2, arrows; inset). Once BeWo cells were cultured under syncytialization conditions, ILK localization shifted over the timecourse of culture to an increased nuclear localization concomitant with decreasing E-cadherin detection in cell-cell adhesions (Fig. 2). However, ILK could still be detected at decreased levels in the cytoplasm at $12 \mathrm{~h}$ and then in the cytoplasm and to focaladhesion like structures at the cell periphery from 24-48 h (Fig. 2). Since BeWo cells grown under syncytialization conditions can achieve up to $80 \%$ syncytialization [33], some BeWo cell clusters do not syncytialize. Interestingly, in these cases we consistently observed that where syncytialization was not evident, as marked by sustained and readily detectable E-cadherin in cell-cell adhesions, ILK localization to cell nuclei was markedly decreased (Fig. 3; $24 \mathrm{~h}$ vs $12 \mathrm{~h}$ panels).

\section{Consequences of ILK fusion protein expression in BeWo cells}

BeWo cells were transfected under proliferating conditions with pEGFP-C3 expression vectors containing wildtype or mutant ILK cDNAs. Cells were then grown under fusion promoting conditions to assess the impacts of the expression of various EGFP-ILK proteins on trophoblast fusion. Transient expression of EGFP-wt-ILK, EGFP-dn-ILK, and EGFP-ca-ILK for $48 \mathrm{~h}$ in BeWo cells under fusion conditions resulted in significant detection of these proteins on immunoblots at the expected $\sim 80$ $\mathrm{kDa}$, in addition to endogenous levels of ILK (Fig. 4). These results confirmed the viability of these vectors and also demonstrated that the expression of the various EGFP-ILK proteins were comparable between the respective transfectants for our studies. The expression of all the EGFP-fusion proteins was also readily observable by immunofluorescence.

During culture of BeWo cells under both proliferating and syncytialization conditions, cells were routinely monitored by phase contrast microscopy to qualitatively assess the condition of the cell cultures. To determine the incidence of syncytialization in transfected cells, the presence (no syncytialization) or absence (syncytialization) of Ecadherin in cell membranes of EGFP-fusion protein 


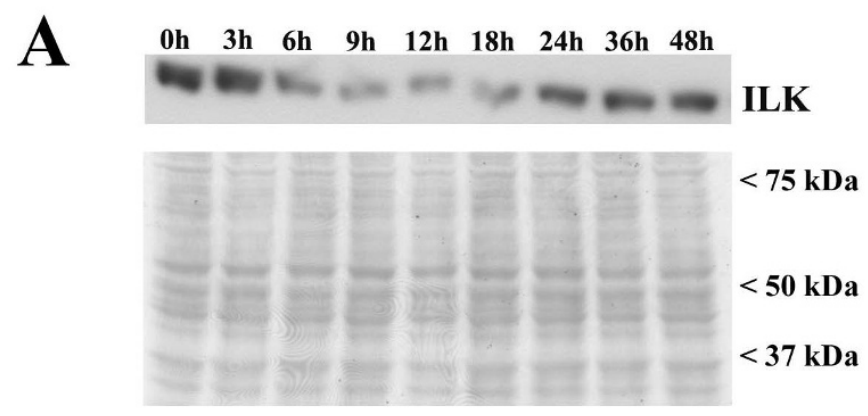

B
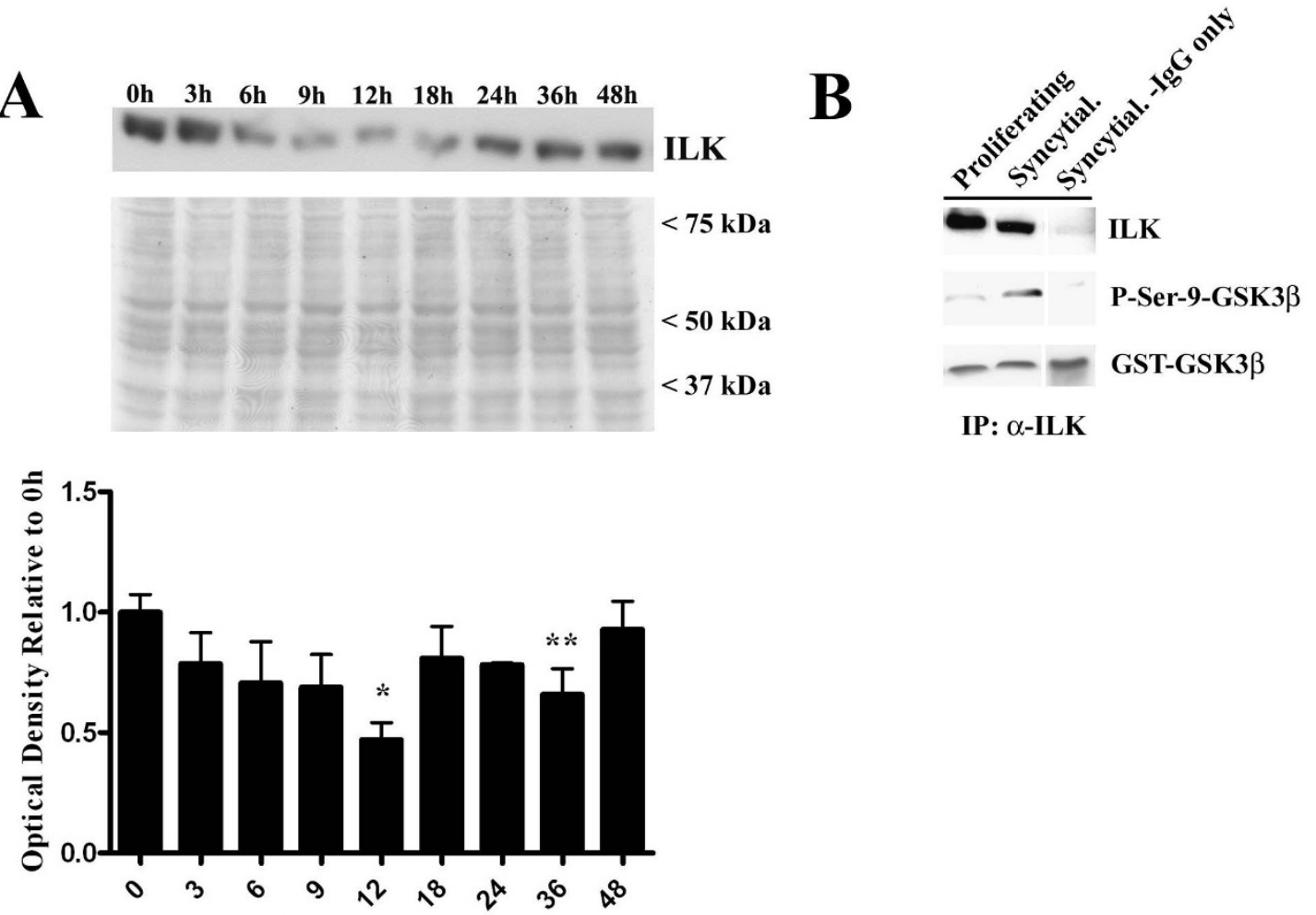

BeWo Cell Culture Time (h)
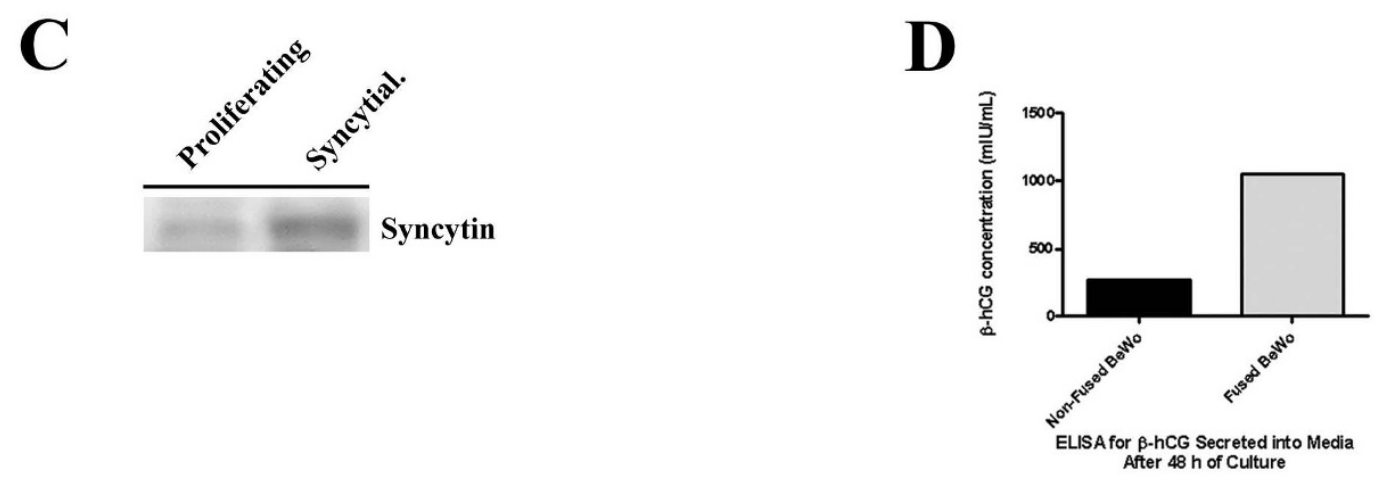

\section{Figure I}

ILK protein expression and catalytic activity during BeWo syncytialization. A) Immunoblot analyses of ILK protein expression during a timecourse $(0 \mathrm{~h}-48 \mathrm{~h})$ of BeWo syncytialization. A representative immunoblot is shown from four independent experiments $(n=4)$. Middle panel is a representative immunoblot stained for total protein demonstrating comparable protein loading between gel lanes. $37 \mathrm{kDa}-75 \mathrm{kDa}$ represent the position of molecular weight markers. The graph demonstrates the densitometric analysis of ILK protein expression during the timecourse $(n=4) . *^{*}<0.05$ vs $0 \mathrm{~h}$ and $48 \mathrm{~h}$; **p $<$ 0.05 vs 0 h. B) Representative immunoblots from in vitro kinase assays $(n=4)$ of ILK catalytic activity in BeWo cells grown under proliferating or syncytialization conditions (Syncytial.). Syncytial. -lgG only = immunoprecipitations with non-specific IgG in place of the primary ILK antisera. P-Ser-9-GSK3 $\beta=$ phosphorylated GST-GSK3 $\beta$ fusion protein. GST-GSK3 $\beta=$ total fusion protein used in the assay. C) A representative immunoblot demonstrating increased syncytin protein expression after $48 \mathrm{~h}$ of BeWo cell culture in syncytialization conditions (Syncytial.) compared to proliferating conditions $(0 \mathrm{~h})$. D) A representative ELISA demonstrating increased $\beta$-hCG secretion from BeWo cells after $48 \mathrm{~h}$ of culture in syncytialization conditions (Fused $\mathrm{BeWo}$ ) compared to cell culture under proliferating (Non-fused BeWo) conditions $(\mathrm{n}=8)$. 
0h
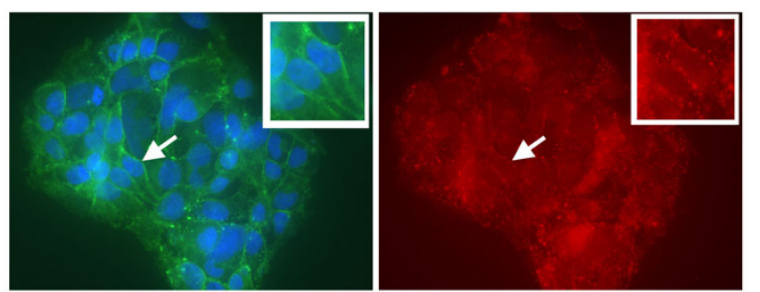

$12 \mathrm{~h}$
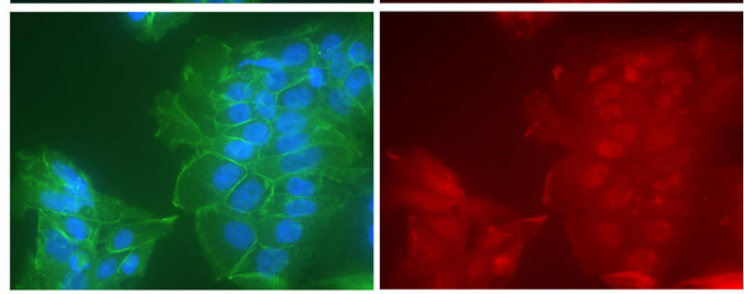

24h
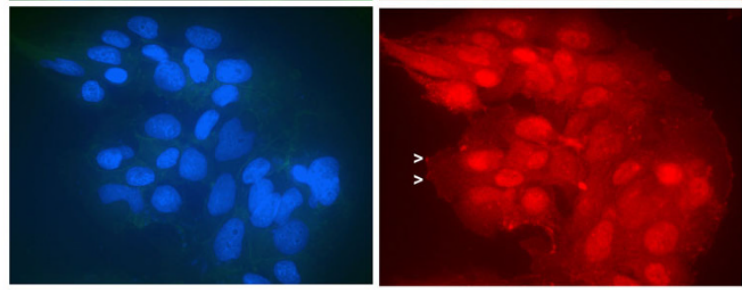

$48 h$
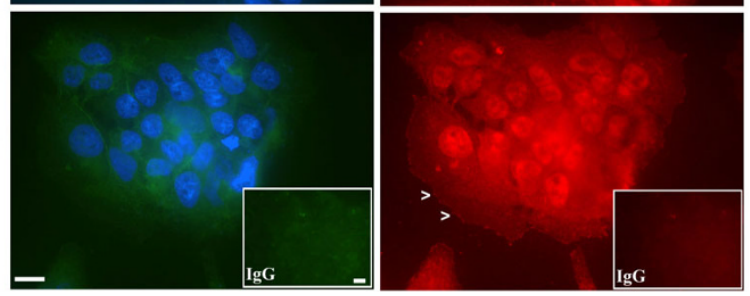

Figure 2

Immunofluorescence analyses for E-cadherin (left panels) and ILK (right panels) protein expression in BeWo cells during a timecourse of syncytialization.

Cells were cultivated under proliferating conditions $(0 \mathrm{~h})$ or syncytialization conditions ( $12 \mathrm{~h}-48 \mathrm{~h})$. With increasing culture time in syncytialization conditions, ILK began to localize to cell nuclei in addition to the cytoplasm and to focal adhesions (arrowheads, $24 \mathrm{~h}-48 \mathrm{~h}$ ). Arrows in $0 \mathrm{~h}$ panels show the position of apparent ILK and E-cadherin co-localization demonstrated in the insets. IgG insets, non-specific lgGs of the appropriate animal species were used as specificity controls in place of the appropriate primary antisera. Nuclei in Ecadherin immunofluorescence panels were stained with DAPI. Scale bars $=25 \mu \mathrm{m}$.

expressing cells was assayed by immunofluorescence analysis (Fig. 5). Transient expression of dn-ILK in BeWo cells resulted in a slight decrease in trophoblast cell fusion, compared to vector control transfected cells, but the decreased levels did not reach statistical significance (Fig. 5; Table 2). In contrast, expression of wt-ILK caused a significant increase in cell fusion, compared to dn-ILK expressing cells $(\mathrm{p}<0.05)$, and expression of ca-ILK in BeWo cells significantly increased cell fusion $(\mathrm{P}<0.05)$ compared to dn-ILK and empty vector expressing cells (Fig. 5; Table 2).
$12 \mathrm{~h}$
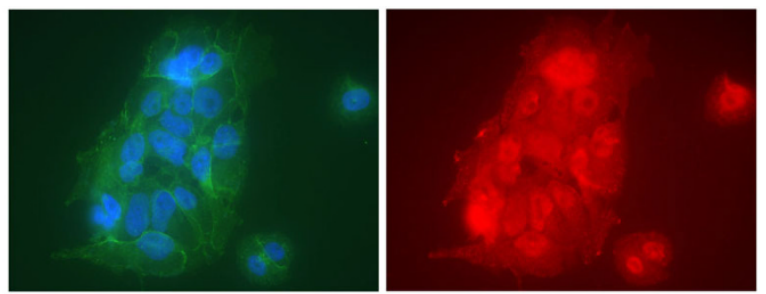

24h
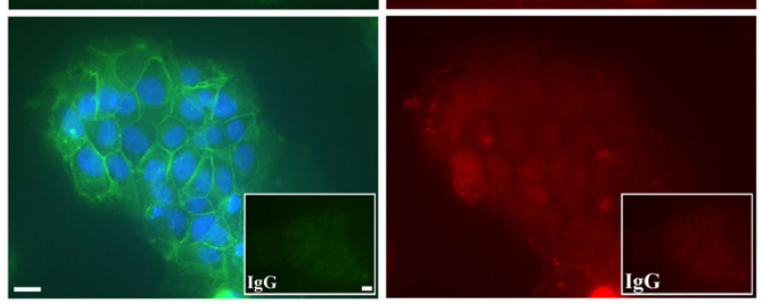

Figure 3

Immunofluorescence analyses for E-cadherin (left panels) and ILK (right panels) protein expression in BeWo cells at $\mathbf{I} 2 \mathrm{~h}$ and $24 \mathrm{~h}$ of cell culture in syncytialization conditions. The images demonstrate that ILK localization to cell nuclei correlates with downregulation of E-cadherin expression at cell-cell membranes. IgG insets, non-specific immunoglobulins of the appropriate animal species were used as specificity controls in place of the appropriate primary antisera. Nuclei in E-cadherin immunofluorescence panels were stained with DAPI. Scale bars $=25 \mu \mathrm{m}$.

Upon stimulation of BeWo cells with forskolin, it is well known that $\beta$-hCG expression and secretion are upregulated [35], thus serving as a marker of trophoblast hormonal differentiation. ELISA analyses of $\beta$-hCG secretion into culture media from transiently transfected BeWo cells demonstrated that any differences in $\beta$-hCG secretion could not be statistically distinguished between the different transfected cells (data not shown) likely due to the background of $\beta$-hCG secretion from non-transfected BeWo cells. Thus, using immunofluorescence analysis we specifically examined the cytoplasmic expression of $\beta$ hCG in transfected BeWo cells (Fig. 6). BeWo cells transfected with empty vector did express some $\beta$-hCG in the cytoplasm but dn-ILK expressing cells showed dramatically reduced ( $\mathrm{p}<0.05) \beta$-hCG expression (Fig. 6; Table $3)$. In contrast, wt-ILK and ca-ILK expressing cells showed markedly enhanced expression ( $\mathrm{p}<0.05)$ of $\beta$-hCG in the cell cytoplasm compared to dn-ILK and vector control cells (Fig. 6; Table 3).

\section{Expression of candidate ILK partners in BeWo syncytialization}

To begin identifying candidate molecules that could partner with ILK to promote syncytialization, we examined a timecourse of BeWo cell syncytialization by immunoblot analysis. Phosphorylated (Ser 473)-Akt expression, a substrate of ILK activity, consistently increased by $48 \mathrm{~h}$ of BeWo culture under syncytialization-promoting condi- 


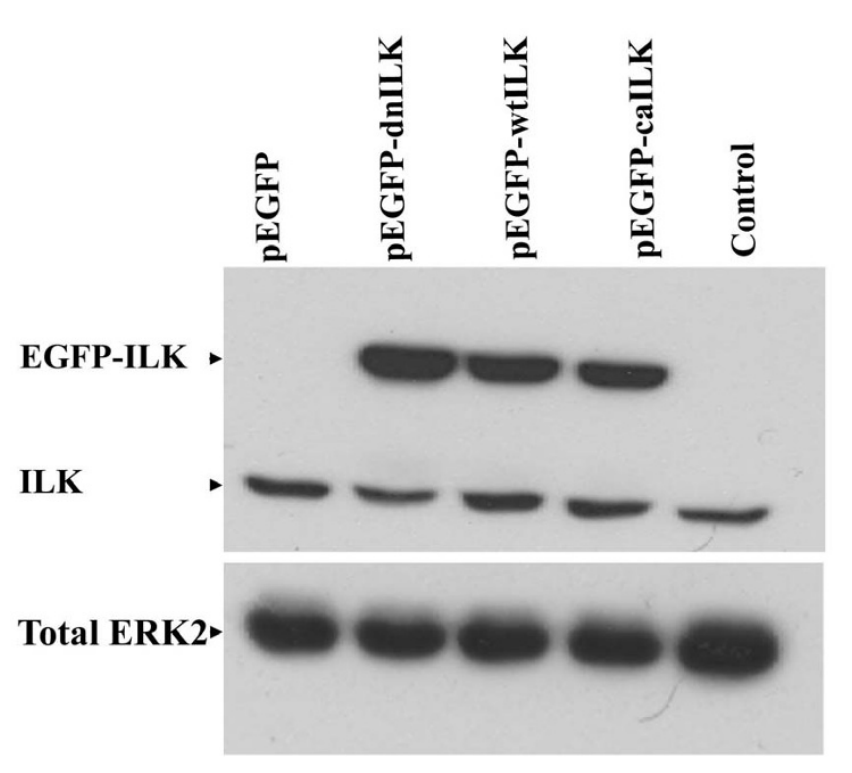

\section{Figure 4}

Immunoblot analysis of transient expression of wildtype (wt), dominant negative (dn), and constitutively active (ca) EGFP-ILK fusion proteins in BeWo cells. A representative immunoblot demonstrating that the EGFP-ILK fusion proteins were readily detectable in BeWo cells $48 \mathrm{~h}$ post-transfection and absent in the empty vector transfected cells (pEGFP). Endogenous ILK (ILK) was detectable in all transfected and non-transfected cell lysates and total ERK2 detection served as an indication of comparable protein loading between lanes.

tions (Fig. 7A, B; 0 h vs 48 h, p < 0.05), in support of our data from in vitro kinase assays of ILK activity at $48 \mathrm{~h}$ of culture (Fig 1B). Furthermore, the expression of the transcriptional repressor Snail was relatively low at $0 \mathrm{~h}$ until after $12 \mathrm{~h}$ of culture in syncytialization conditions then also became highly expressed by $48 \mathrm{~h}$ compared to $0 \mathrm{~h}$ (Fig. 7A, C; p < 0.05). Thus, increased ILK activity appears to correlate with increased Snail expression during syncytialization and decreased detection of E-cadherin at cellcell adhesions (Figs. 1, 2, 7).

\section{Discussion}

Despite well known roles for ILK in cell-ECM adhesion and signal transduction $[20,21]$, ILK also appears to be involved in integrin-independent epithelial cell-cell adhesion $[38,39]$. We have previously reported that ILK was highly expressed in villous cytotrophoblast cells in first trimester and early second trimester human chorionic floating villi, but that it was barely detected in the syncytiotrophoblast layer [22]. The adherens junction protein Ecadherin is also highly detectable in human cytotrophoblast and loss of E-cadherin in cytotrophoblast is associated with syncytialization [24-27]. Importantly, ILK appears to regulate E-cadherin expression $[28,29]$. Thus, using the
BeWo trophoblast cell line model we examined ILK expression in BeWo cells during syncytialization and tested the hypothesis that ILK could facilitate the differentiation and fusion of cytotrophoblast into the syncytiotrophoblast.

\section{Temporal and spatial expression of ILK is dynamically altered during syncytialization}

Examination of ILK kinase activity during syncytialization revealed that ILK activity is increased during syncytialization. This could lead to increased ILK-Akt signaling as Akt is a substrate of ILK. While total ILK expression was significantly lower by $12 \mathrm{~h}$ (vs $0 \mathrm{~h}$ ) of culture in syncytialization conditions, expression quickly recovered and reached detection levels at $48 \mathrm{~h}$ of culture that were comparable to ILK expression at $0 \mathrm{~h}$. However, more dramatic changes in spatial expression of ILK were apparent during syncytialization as ILK began accumulating in cell nuclei. Recent work by Acconcia et al [40] demonstrated that ILK can localize to both cell cytoplasm and cell nuclei and that ILK contains both functional nuclear localization and nuclear export sequences. Furthermore, in MCF7 and NIH 3T3 cells ILK nuclear localization appears important for nuclear integrity and ILK can associate with chromatin. Since changes in ILK expression and catalytic activity were associated with BeWo syncytialization, we examined whether or not exogenous ILK overexpression in BeWo cells could facilitate the process.

\section{ILK facilitates BeWo syncytialization}

The examination of the presence or absence of desmosomal or adherens junction (E-cadherin) proteins has been successfully used for evaluating the incidence of fusion in trophoblast $[18,24,26,41,42]$. Thus, we also scored the incidence of syncytium formation in BeWo cells overexpressing EGFP-ILK fusion proteins by examining the presence or absence of E-cadherin immunolocalization. Transient expression of wt-ILK in BeWo cells significantly increased trophoblast syncytialization compared to dn-ILK while ca-ILK expression significantly increased syncytialization compared to vector control and dn-ILK expressing BeWo cells. The ILK constructs used for our experiments have been utilized by other laboratories, including ours, in a number of cell types [20,21]. We have previously demonstrated that transient expression of dnILK in the extravillous trophoblast cell line model HTR8SVneo significantly reduced trophoblast migration compared to cells expressing wt-ILK [22]. The over-expression of wt-ILK in a number of cell types can lead to phosphorylation of Akt and GSK3- $\beta$ while the active mutant ca-ILK has been shown to constitutively phosphorylate Akt [4345]. The dominant negative mutant ILK was originally considered a kinase dead mutant, but has since been shown to have $20 \%$ kinase activity in vitro [45-47] be deficient in $\alpha$-parvin and paxillin interaction, and to be 

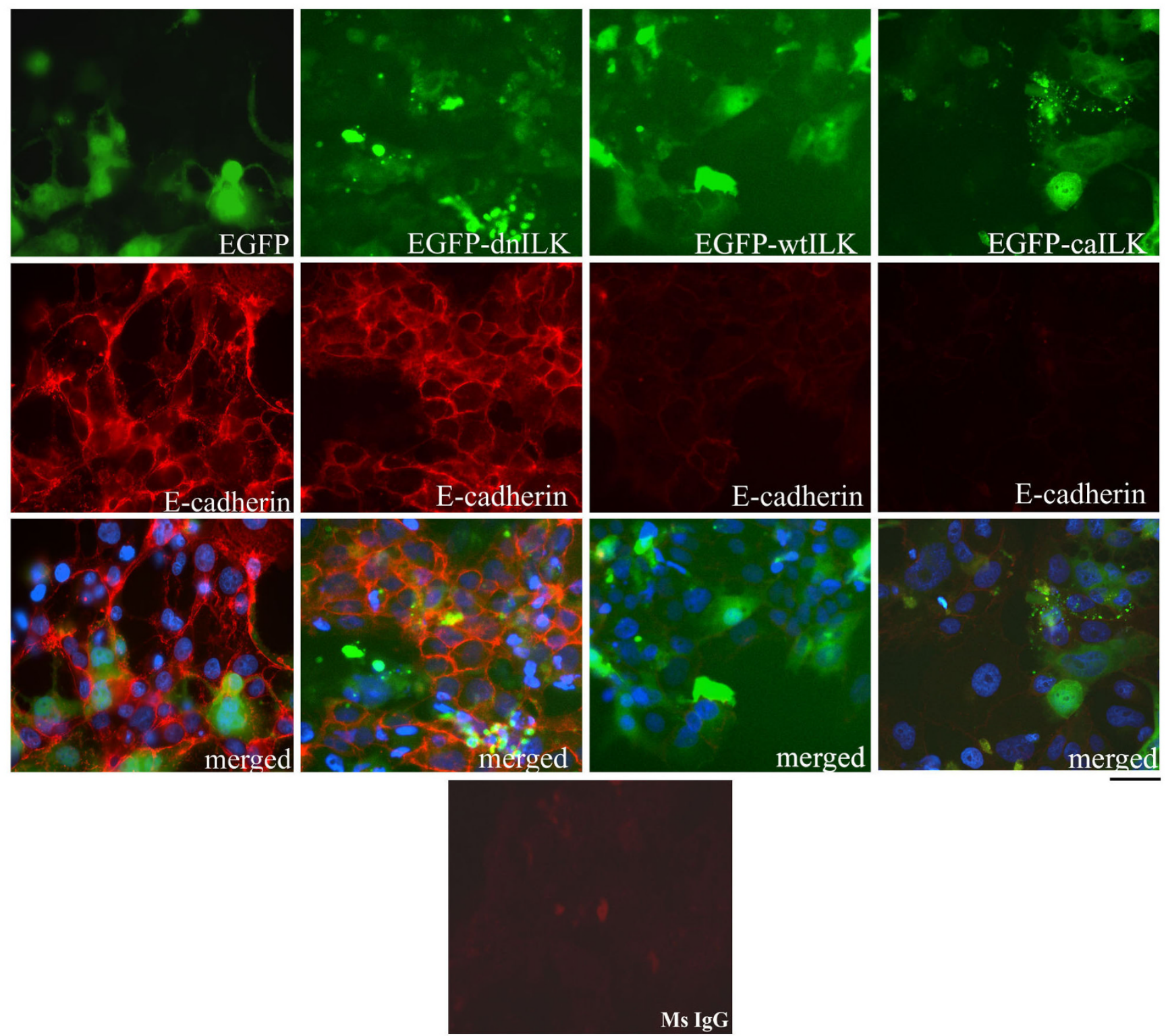

\section{Figure 5}

Immunocytochemical analysis of E-cadherin expression in BeWo cells transiently transfected with either pEGFP-C3 vector (EGFP), pEGFP-C3 containing dominant negative ILK (EGFP-dnILK), wildtype ILK (EGFPwt ILK) or constitutively active ILK (EGFP-ca ILK) and cultivated under syncytialization conditions for $48 \mathrm{~h}$. Ms $\lg G=$ mouse IgG negative control. Scale bar $=50 \mu \mathrm{m}$. Data are representative of three independent experiments.

incapable of incorporating into focal adhesions thus remaining only in the cytoplasm $[48,49]$. Therefore, it appears to exert a strong dominant negative effect by maintaining ILK associated proteins in an inappropriate subcellular location (e.g. not focal adhesions) [49].

Since dn-ILK expressing BeWo cells only displayed a slightly reduced level of syncytialization compared to vector control cells, it would appear that lack of focal adhesion incorporation of ILK-associated proteins, but not likely $\alpha$-parvin or paxillin, does not significantly impact BeWo syncytialization. Furthermore, the likelihood of residual kinase activity from this mutant (not fully kinase dead) may account for the less than significant reduction in syncytialization in dn-ILK expressing BeWo cells. Transient expression of wt-ILK in BeWo cells did not significantly increase trophoblast syncytialization compared to vector control expressing cells. ILK activity is dependent on PI-3 kinase activity in vivo [21] and, as a result, it is possible that the overexpression of the wt-ILK fusion pro- 
Table 2: The incidence of BeWo syncytialization. The incidence of BeWo syncytialization was determined by scoring the absence of $E$ cadherin immunolocalization in groups of EGFP-fusion protein expressing cells. Data are from three independent experiments.

\begin{tabular}{lllll}
\hline Experiment & BeWo + pEGFP-C3 & BeWo + pEGFP-C3 -dn-ILK & BeWo + pEGFP-C3 - wt-ILK & BeWo + pEGFP-C3- ca-ILK \\
\hline 1 & $28 / 43$ & $11 / 38$ & $35 / 48$ & $38 / 43$ \\
2 & $26 / 51$ & $39 / 63$ & $66 / 72$ & $32 / 35$ \\
3 & $21 / 50$ & $14 / 47$ & $19 / 32$ & $27 / 37$ \\
$\begin{array}{l}\text { Avg. Incidence } \\
(\% \text { of } 1.00+/ \text { SEM) }\end{array}$ & $0.52+/-0.07$ & $0.42+/-0.10$ & $\mathrm{a} 0.73+/-0.09$ & $\mathrm{~b} 0.85+/-0.06$ \\
\hline
\end{tabular}

a: Syncytialization was significantly elevated in cells expressing wildtype (wt)-ILK versus dominant negative (dn)-ILK expressing cells ( $p<0.05)$ b: Syncytialization was significantly increased in BeWo cells expressing constitutively active (ca)-ILK vs cells containing pEGFP-C3 (empty vector) or dn-ILK $(p<0.05)$

tein may have saturated the endogenous PI-3 kinase resulting in low activation levels of the exogenous wt-ILK fusion protein. In contrast, our results with ca-ILK expressing BeWo cells indicate that ILK facilitates BeWo trophoblast syncytialization and that it is likely dependent, at least in part, on ILK catalytic activity. Fusion-promoting culture conditions, particularly elevated cAMP levels and PKA activation induced by forskolin addition $[32,50]$, also likely synergize with ILK catalytic activity to aid syncytialization as ILK-induced syncytialization was absent in BeWo cells grown only under proliferation-promoting conditions (data not shown). In total, our results clearly correlate with work by Miller et al [51] who demonstrated that over-expression of ILK in L6 myoblasts resulted in increased ILK activity and stimulation of myoblast fusion into myotubes.

\section{ILK induces intracellular $\beta$-hCG expression}

The synthesis and secretion of $\beta$-hCG is a marker of syncytiotrophoblast differentiation [6] and syncytializing BeWo cells also express $\beta$-hCG mRNA and protein when cultivated under fusion-promoting conditions $[15,34,35]$. In our experiments we examined $\beta$-hCG expression in transfected cells using immunocytochemistry, as has been previously done [34], since our transient transfection strategy meant there was a background of $\beta$-hCG expres- sion and secretion from untransfected cells. In vector control cells we detected some $\beta$-hCG expression as a result of culture in fusion-promoting conditions; however, dn-ILK expressing cells exhibited significantly lower levels of $\beta$ hCG expression in situ compared to vector controls and the other mutant ILK protein expressing cells. Thus, in contrast to syncytialization, lack of proper subcellular localization of ILK-associated proteins (dominant negative effect) does impact BeWo cell $\beta$-hCG expression and differentiation. Furthermore, with the concern above regarding proper catalytic activation of exogenous wt-ILK in transfected BeWo cells, the significant increase in $\beta$ hCG expression in these cells vs dn-ILK and vector controls may also indicate a need for ILK, in addition to catalytic activity, as an adapter protein and signaling platform for other signalling proteins to aid proper hormonal differentiation. What specific ILK-associated protein(s) may be involved in hormonal differentiation of BeWo cells is under investigation. The significant upregulation of $\beta$ hCG expression in ca-ILK expressing BeWo cells highlights that ILK catalytic activity, at least in part, also has a role in promoting syncytiotrophoblast differentiation.

\section{Candidate ILK signalling pathway}

The underlying signaling mechanism that could be responsible for ILK facilitated syncytialization of BeWo

Table 3: The incidence of $\beta$-human chorionic gonadotropin ( $\beta$-hCG) expression. The incidence of $\beta$-hCG expression was determined by the presence of $\beta$-hCG immunolocalization in groups of EGFP-fusion protein expressing cells. Data are from three independent experiments.

\begin{tabular}{lllll}
\hline Experiment & BeWo + pEGFP-C3 & BeWo + pEGFP-C3- dn-ILK & BeWo + pEGFP-C3- wt-ILK & BeWo + pEGFP-C3- ca-ILK \\
\hline 1 & $16 / 40$ & $13 / 68$ & $27 / 47$ & $46 / 57$ \\
2 & $23 / 57$ & $8 / 51$ & $30 / 47$ & $49 / 61$ \\
3 & $20 / 43$ & $15 / 55$ & $22 / 36$ & $38 / 55$ \\
$\begin{array}{l}\text { Avg. Incidence } \\
(\% \text { of } 1.00+/-S E M)\end{array}$ & $0.43+/-0.02$ & $\mathrm{a} 0.22+/-0.03$ & $\mathrm{~b} 0.62+/-0.02$ & $\mathrm{~b}, 0.77+/-0.04$ \\
\hline
\end{tabular}

a: Cytoplasmic $\beta$-hCG expression markedly decreased in cells expressing dominant negative $(\mathrm{dn})$-ILK relative to pEGFP-C3 (empty vector) cells (p $<0.05)$

b: Expression was significantly increased in cells expressing wildtype (wt)- and constitutively active (ca)-ILK compared to cells expressing empty vector or dn-ILK $(p<0.05)$

c: Cytoplasmic $\beta$-hCG expression was significantly increased in cells expressing ca-ILK compared to cells expressing wt-ILK ( $<<0.05)$ 

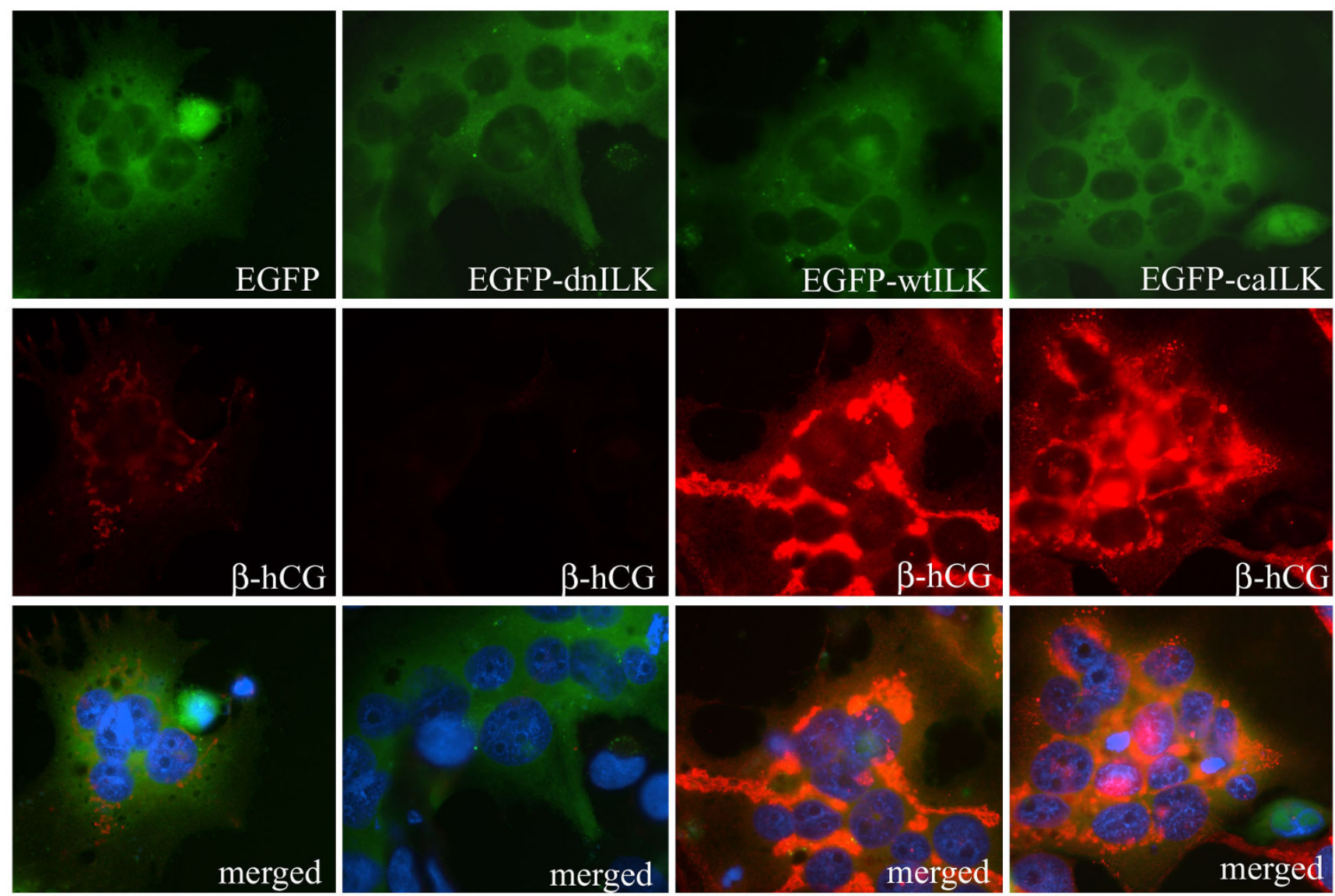

Rb IgG

\section{Figure 6}

Immunocytochemical analysis of $\beta$-human chorionic gonadotropin ( $\beta$-hCG) expression in BeWo cells transiently transfected with pEGFP-C3 vector (EGFP), pEGFP-C3 containing dominant negative ILK (EGFP-dn ILK), wildtype ILK (EGFP-wt ILK) or constitutively active ILK (EGFP-ca ILK) and cultivated under syncytialization conditions for $\mathbf{4 8 ~ h}$. Rb lgG = rabbit IgG negative control. Scale bar $=25 \mu \mathrm{m}$. Data are representative of three independent experiments.

cells may involve Snail, a sensitive transcriptional repressor of E-cadherin expression. Tan et al [29] have previously demonstrated that over-expression of ILK in human colon carcinoma cell lines stimulated Snail expression. Recently, these results were extended in Scp2 mouse mammary epithelial cells where ILK over-expression resulted in stimulation of Snail expression and loss of Ecadherin expression [52]. Alternatively, depletion of ILK, Akt, or Snail resulted in upregulation of E-cadherin expression. The authors also identified Poly (ADP-ribose) polymerase-1 (PARP-1) as a component of the signaling pathway upstream of Snail leading to downregulation of E-cadherin expression [52]. Our results clearly establish a correlation of increased ILK activity and alterations in ILK expression, including nuclear localization of ILK, during BeWo syncytialization with increased Snail expression in these cells during this process. With reports of Snail involved in promoting epithelial-mesenchymal transition 

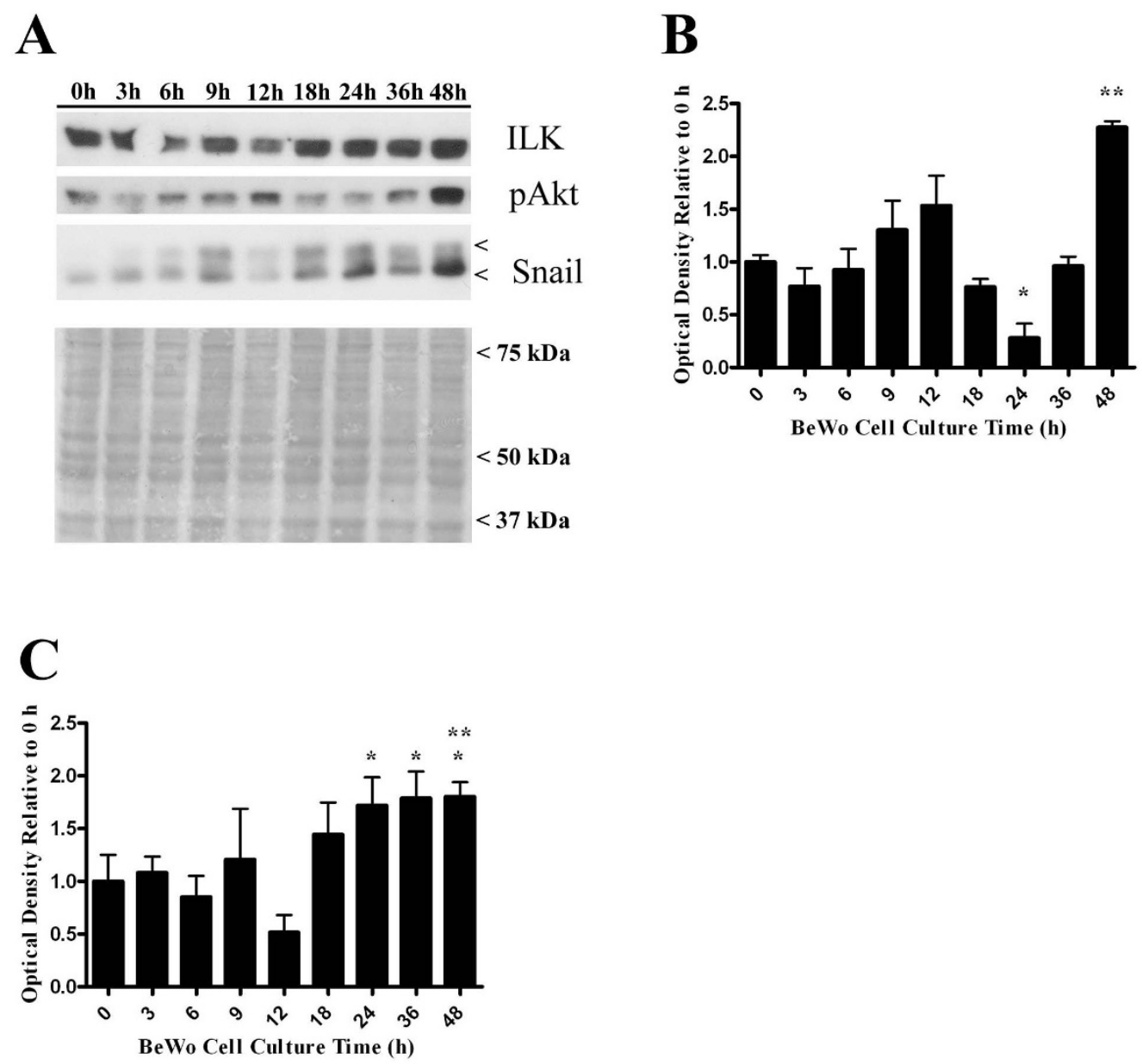

\section{Figure 7}

ILK, pAkt, and Snail protein expression during a timecourse of BeWo syncytialization. A) Representative immunoblots from four independent experiments $(n=4)$ are shown with a representative immunoblot stained for total protein to illustrate comparable protein loading of all gel lanes. B) Densitometric analysis of pAkt expression during BeWo cell culture in syncytialization conditions demonstrating a significant decrease in pAkt expression by $24 \mathrm{~h}(\mathrm{p}<0.05)$ compared to $0,9,12$ and $48 \mathrm{~h}$ and a rapid increase in pAkt expression by $48 \mathrm{~h}$ of culture compared to $0 \mathrm{~h}(\mathrm{p}<0.05, \mathrm{n}=4)$. C) Densitometric analysis of Snail protein expression during BeWo cell culture in syncytialization conditions demonstrating that Snail expression becomes significantly elevated at 24,36 and $48 \mathrm{~h}$ vs $12 \mathrm{~h}(\mathrm{p}<0.05, \mathrm{n}=4)$ and at $48 \mathrm{~h}$ of culture compared to expression in proliferating conditions at 0 h $(p<0.05, n=4)$.

by downregulating E-cadherin expression through an ILKAkt-Snail pathway [29,52], our study also implicates this pathway in facilitating syncytialization of BeWo trophoblast cells. Identification of additional members of this ILK signaling pathway and the specific interactions and role(s) of all these proteins in trophoblast syncytialization is ongoing.

Impaired trophoblast fusion and differentiation appears to be directly associated with pathological conditions such as preeclampsia or fetal growth restriction [14]. Using DNA microarray analysis, Kudo et al [35] reported that genes involved in cell and tissue structural dynamics appeared to be very important for syncytialization. Given the role of ILK in such processes, we appear to have identified a new protein involved in trophoblast syncytialization and differentiation for future study. In addition, our research also raises the possibility of a more general role for ILK in cell-cell fusion per se as this fusion process has been suspected in breast cancer cells and demonstrated in macrophages and myoblasts - and all of which can highly express ILK [51,53-56].

\section{Conclusion}

These findings demonstrate that ILK activity and expression play a novel role in syncytialization and differentiation of BeWo cells, and implicate ILK in the same process in villous cytotrophoblasts in vivo. 


\section{Competing interests}

The authors declare that they have no competing interests.

\section{Authors' contributions}

TB carried out the experiments and contributed to the writing of the manuscript. PE was involved in the cultivation of the BeWo. GH contributed the expression vectors that were constructed and tested in his laboratory. DJM conceived and designed the study, assisted with statistical analyses and assisted with drafting of the manuscript. All authors read and approved the final manuscript.

\section{Acknowledgements}

The authors would like to acknowledge the aid of Bryan G. White for helpful comments during the research project. The research described in this manuscript was funded by an operating grant (\#ROP-82354) from the Canadian Institutes of Health Research (CIHR) and the Industrial Research and Innovation Fund (IRIF, Government of Newfoundland and Labrador). The research was also aided by a New Opportunities Fund infrastructure grant from the Canada Foundation for Innovation (Project \# 74II9). TB was partially supported by a Deans' Fellowship from Research and Graduate Studies in the Faculty of Medicine at Memorial University of Newfoundland. PE was supported by a CIHR/Strategic Initiative for Research in the Reproductive Health Sciences (STIRRHS) Fellowship.

\section{References}

I. Norwitz ER, Schust DJ, Fisher SJ: Implantation and the survival of early pregnancy. New Engl J Med 200I, 345:|400-|408.

2. Georgiades P, Ferguson-Smith AC, Burton GJ: Comparative developmental anatomy of the murine and human definitive placentae. Placenta 2002, 23:3-19.

3. Red-Horse K, Zhou Y, Genbacev O, Prakobphol A, Foulk R, McMaster M, Fisher SJ: Trophoblast differentiation during embryo implantation and formation of the maternal-fetal interface. J Clin Invest 2004, I | 4:744-754.

4. Bischof $P$, Irminger-Finger I: The human cytotrophoblastic cell, a mononuclear chameleon. Int J Biochem Cell Biol 2005, 37:I-I6.

5. Kaufmann P, Black S, Huppertz B: Endovascular trophoblast invasion: implications for the pathogenesis of intrauterine growth retardation and preeclampsia. Biol Reprod 2003, 69:1-7.

6. Bernischke K, Kaufmann P, Baergen R: Pathology of the human placenta 5th edition. New York: Springer Science; 2006.

7. Huppertz B, Frank HG, Kingdom JCP, Reister F, Kaufmann P: Villous cytotrophoblast regulation of the syncytial apoptotic cascade in the human placenta. Histochem Cell Biol 1998, I I 0:495-508.

8. Ellery PM, Cindrova-Davies T, Jauniaux E, Ferguson-Smith AC, Burton G): Evidence for transcriptional activity in the syncytiotrophoblast of the human placenta. Placenta 2009, 30:329-334.

9. Mori M, Ishikawa G, Luo S-S, Mishima T, Goto T, Robinson JM, Matsubara S, Takeshita T, Kataoka H, Takizawa T: The cytotrophoblast layer of human chorionic villi becomes thinner but maintains its structural integrity during gestation. Biol Reprod 2007, 76: I64-I72.

10. Jones CJ, Harris LK, Whittingham J, Aplin JD, Mayhew TM: A reappraisal of the morphophenotype and basal lamina coverage of cytotrophoblasts in human term placenta. Placenta 2008, 29:215-219.

II. Black S, Kadyrov M, Kaufmann P, Ugele B, Emans N, Huppertz B: Syncytial fusion of human trophoblast depends on caspase-8. Cell Death Differ. 2004, I I(I):90-98.

12. Huppertz B, Kaufmann P, Kingdom JCP: Trophoblast turnover in health and disease. Fetal Matern Med Rev 2002, I 3:17-32.

13. Lyden $\mathrm{TW}, \mathrm{Ng} \mathrm{AK}$, Rote $\mathrm{N}$ : Modulation of phosphatidylserine epitope expression by BeWo cells during forskolin treatment. Placenta 1993, I4:177-186.

14. Huppertz B, Bartz C, Kokozidou M: Trophoblast fusion: fusogenic proteins, syncytins and ADAMs, and other prerequisites for syncytial fusion. Micron 2006, 37:506-5I7.
15. Frendo J-L, Olivier D, Cheynet V, Blond J-L, Boston O, Vidaud M, Rabreau M, Evain-Brion D, Mallet F: Direct involvement of HERV$W$ env glycoprotein in human trophoblast cell fusion and differentiation. Mol Cell Biol 2003, 23:3566-3574.

16. Yu C, Shen K, Lin M, Chen P, Lin C, Chang GD, Chen H: GCMa regulates the syncytin-mediated trophoblast fusion. J Biol Chem 2002, 277:50062-50068.

17. Baczyk D, Satkunaratnam A, Nait-Oumesmar B, Huppertz B, Cross JC, Kingdom JC: Complex patterns of GCMI mRNA and protein in villous and extravillous trophoblast cells of the human placenta. Placenta 2004, 25:553-559.

18. Daoud G, Rassart E, Masse A, Lafond J: Src family kinases play multiple roles in differentiation of trophoblasts from human term placenta. J Physiol J Physiol. 2006 Mar 15;57 (Pt 3):537-53. 2006, 57 I (Pt 3):537-553.

19. Vargas A, Moreau J, Le Bellego F, Lafond J, Barbeau B: Induction of trophoblast cell fusion by a protein tyrosine phosphatase inhibitor. Placenta 2008, 29:70-I74.

20. Boulter E, Van Obberghen-Schilling E: Integrin-linked kinase and its partners: A modular platform regulating cell-matrix adhesion dynamics and cytoskeletal organization. Eur J Cell Biol 2006, 85:255-263.

21. Legate KR, Montanez E, Kudlacek O, Fassler R: ILK, PINCH, and parvin: the tIPP of integrin signalling. Nature Mol Cell Bio 2006, 7:20-31.

22. Elustondo P, Hannigan GE, Caniggia I, MacPhee DJ: Integrin-Linked Kinase (ILK) is highly expressed in first trimester human chorionic villi and regulates migration of a human cytotrophoblast-derived cell line. Biol Reprod 2006, 74:959-968.

23. Yap AS, Crampton MS, Hardin J: Making and breaking contacts: the cellular biology of cadherin regulation. Curr Opin Cell Biol 2007, 19:508-514.

24. Coutifaris C, Kao LC, Sehdev HM, Chin U, Babalola GO, Blaschuk OW, Strauss JF III: E-cadherin expression during the differentiation of human trophoblasts. Development I99|, I I 3(3):767-777.

25. Getsios S, Chen G, MacCalman C: $\alpha-, \beta-, \gamma$-catenin, and p I 20ctn, expression during the terminal differentiation and fusion of human mononucleate cytotrophoblast in vitro and in vivo. Mol Reprod Dev 200I, 59:I68-177.

26. Getsios S, MacCalman CD: Cadherin-I I modules the terminal differentiation and fusion of human trophoblastic cells in vitro. Dev Biol 2003, 257:4I-54

27. Brown LM, Lacey HA, Baker PN, Crocker IP: E-cadherin in the assessment of aberrant placental cytotrophoblast turnover in pregnancies complicated by pre-eclampsia. Histochem Cell Biol 2005, I 24:499-506.

28. Hannigan GE, Leung-Hagesteijn C, Fitz-Gibbon L, Coppolino MG, Radeva G, Filmus J, Bell JC, Dedhar S: Regulation of cell adhesion and anchorage-dependent growth by a new $\beta I$-integrinlinked protein kinase. Nature 1996, 379:91-96.

29. Tan C, Costello P, Sanghera J, Dominguez D, Baulida J, Garcia de Herreros A, Dedhar S: Inhibition of integrin linked kinase (ILK) suppresses $\beta$-catenin-Lef/Tcf-dependent transcription and expression of the E-cadherin repressor, snail, in APC -/human colon carcinoma cells. Oncogene 200I, 20:I33-I40.

30. Borges M, Bose P, Frank HG, Kaufmann P, Potgens A: A two colour fluorescence assay for the measurement of syncytial fusion between trophoblast derived cell lines. Placenta 2003, 24:959-964

31. Potgens AJG, Drewlo S, Kokozidou M, Kaufmann P: Syncytin: the major regulator of trophoblast fusion? Recent developments and hypotheses on its action. Hum Reprod Update 2004, I 0(6):487-496.

32. Wice B, Menton D, Geuze H, Schwartz AL: Modulators of cAMP metabolism induce syncytialization formation in vitro. Exp Cell Res 1990, 186:306-316.

33. Rote NS: Intercellular fusion of BeWo. Placenta 2005, 26:686.

34. Lin L, Xu B, Rote NS: The cellular mechanism by which the human endogenous retrovirus ERV-3 env gene affects proliferation and differentiation in a human placental trophoblast model, BeWo. Placenta 2000, 21 :73-78.

35. Kudo Y, Boyd CAR, Sargent IL, Redman CWG, Lee JM, Freeman TC: An analysis using DNA microarray of the time course of gene expression during syncytialization of a human placental cell line (BeWo). Placenta 2004, 25:479-488. 
36. Kudo Y, Boyd CAR: Changes in expression and function of syncytin and its receptor, amino acid transport system B (ASCT2), in human placental choriocarcinoma BeWo cells during syncytialization. Placenta 2002, 23:536-54I.

37. Nasiry SA, Spitz B, Hanssens M, Luyten C, Pijnenborg R: Differential effects of inducers of syncytialization and apoptosis on BeWo and JEG-3 choriocarcinoma cells. Hum Reprod 2006, 2I(I): 193-20I.

38. Vespa A, Darmon AJ, Turner CE, D'Souza SJA, Dagnino L: Ca2+dependent localization of integrin-linked kinase to cell junctions in differentiating keratinocytes. J Biol Chem 2003, 278: II 528-11535.

39. Vespa A, D'Souza SJ, Dagnino L: A novel role for integrin-linked kinase in epithelial sheet morphogenesis. Mol Biol Cell 2005, I 6:4084-4095.

40. Acconcia F, Barnes CJ, Singh RR, Talukder AH, Kumar R: Phosphorylation-dependent regulation of nuclear localization and functions of integrin-linked kinase. Proc Natl Acad Sci USA 2007, 104:6782-6787.

4I. Das M, Xu B, Lin L, Chakrabarti S, Shivaswamy V, Rote NS: Phosphatidylserine efflux and intercellular fusion in a BeWo model of human villous cytrophoblast. Placenta 2004, 25:396-407.

42. Daoud G, Amyot M, Rassart E, Masse A, Simoneau L, Lafond J: ERKI/ 2 and $\mathrm{p} 38$ regulate trophoblast differentiation in human term placenta. J Physiol 2005, 566.2:409-423.

43. Lynch DK, Ellis CA, Edwards PAW, Hiles ID: Integrin-linked kinase regulates phosphorylation of serine 473 of protein kinase B by an indirect mechanism. Oncogene 1999, 18:8024-8032.

44. Persad S, Attwell S, Gray V, Delcommenne M, Troussard AA, Sanghera J, Dedhar S: Inhibition of integrin-linked kinase (ILK) suppresses activation of protein kinase B/Akt and induces cell cycle arrest and apoptosis of PTEN-mutant prostate cancer cells. Proc Natl Acad Sci USA 2000, 97:3207-32I 2.

45. Persad S, Attwell S, Gray V, Mawji N, Deng JT, Leung D, Yan J, Sanghera J, Walsh MP, Dedhar S: Regulation of protein kinase B/Aktserine $\mathbf{4 7 3}$ phosphorylation by integrin-linked kinase. J Biol Chem 200I, 276:27462-27469.

46. Delcommenne M, Tan C, Gray V, Rue L, Woodgett JR, Dedhar S: Phosphoinositide-3-OH kinase-dependent regulation of glycogen synthase kinase 3 and protein kinase B/AKT by the integrin-linked kinase. Proc Natl Acad Sci USA 1998, 95:I1211-11216.

47. Novak A, Hsu S-C, Leung-Hagesteijn C, Radeva G, Papkoff J, Montesano R, Roskelley C, Grosschedll R, Dedhar S: Proc Natl Acad Sci USA 1998, 95:4374-4379.

48. Yamaji S, Suzuki Y, Sugiyama $Y$, Koide $Y$, Yoshida H, Kanamori $H$, Mohri $\mathrm{H}$, Ohno $\mathrm{S}$, Ishigatsubo $\mathrm{Y}$ : A novel integrin-linked kinasebinding protein, affixin, is involved in the early stage of cellsubstrate interaction. / Cell Biol 200 I, I 53:|25I-I 264.

49. Nikolopoulous SN, Turner CE: Molecular dissection of actopaxin-integrin-linked kinase-paxillin interactions and their role in subcellular localization. J Biol Chem 2002, 277:1568-1575.

50. Knerr I, Schubert SW, Wich C, Amann K, Aigner T, Vogler T, Jung R, Dotsch J, Rascher W, Hashelmolhosseini S: Stimulation of GCMIa and syncytin via cAMP mediated PKA signaling in human trophoblastic cells under normoxic and hypoxic conditions. FEBS Lett 2005, 579:399|-3998.

51. Miller MG, Naruszewicz I, Kumar AS, Ramlal T, Hannigan GE: Integrin-linked kinase is a positive mediator of $\mathrm{L} 6$ myoblast differentiation. Biochem Biophys Res Commun 2003, 3 1 0:796-803.

52. McPhee TR, McDonald PC, Oloumi A, Dedhar S: Integrin-linked kinase regulates E-cadherin expression through PARP-I. Dev Dyn 2008, 237:2737-2747.

53. Tan C, Mui A, Dedhar S: Integrin-linked kinase regulates inducible nitric oxide synthase and cyclooxygenase- 2 expression in an NF-kappa B-dependent manner. J Biol Chem 2002, 277:3109-3II6

54. Mongroo PS, Johnstone CN, Naruszewicz I, Leung-Hagesteijn C, Sung RK, Carnio L, Rustgi AK, Hannigan GE: Beta-parvin inhibits integrin-linked kinase signaling and is downregulated in breast cancer. Oncogene 2004, 23:8959-8970.

55. Chen EH, Grote E, Mohler W, Vignery A: Cell-cell fusion. FEBS Lett 2007, 58I:2I8I-2193.
56. Larsson L-I, Bjerregaard B, Wulf-Andersen L, Talts JF: Syncytin and cancer cell fusions. Directions in Science 2007, 7: I 193-1 197.
Publish with Bio Med Central and every scientist can read your work free of charge

"BioMed Central will be the most significant development for disseminating the results of biomedical research in our lifetime. "

Sir Paul Nurse, Cancer Research UK

Your research papers will be:

- available free of charge to the entire biomedical community

- peer reviewed and published immediately upon acceptance

- cited in PubMed and archived on PubMed Central

- yours - you keep the copyright

Submit your manuscript here:

http://www.biomedcentral.com/info/publishing_adv.asp
BioMedcentral 